Review Article

\title{
Physicochemical features, functional characteristics, and health benefits of cottonseed oil: a review
}

\author{
Benefícios à saúde humana e características físico-químicas e funcionais do óleo de \\ semente de algodão: uma revisão
}

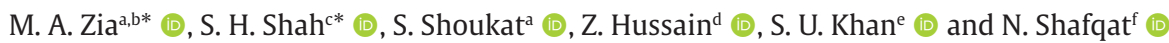 \\ aNational Agricultural Research Centre - NARC, National Institute for Genomics and Advanced Biotechnology - NIGAB, Islamabad, Pakistan \\ 'Quaid-i-Azam University, Department of Biotechnology, Islamabad, Pakistan \\ 'Allama Iqbal Open University, Faculty of Sciences, Department of Agricultural Sciences, Islamabad, Pakistan \\ dUniversity of Swat, Centre for Biotechnology and Microbiology, Khyber Pukhtunkhwa, Pakistan \\ ${ }^{e}$ Chinese Academy of Agricultural Sciences - CAAS, Biotechnology Research Institute, Biotechnology Research Institute, Beijing, P.R. China \\ fHazara University, Department of Agricultural Sciences, Mansehra, Pakistan
}

\begin{abstract}
Vegetable oils have their specific physicochemical properties due to which they are playing vital role in human nutritional diet for health benefits. Cottonseed oil is obtained from various species of cotton seeds that are famous to be grown mainly for their fiber quality. The most prominently used specie is Gossypium hirsutum. It is obvious that the seeds of different variety of cotton vary as grown in diverse agroclimatic conditions with respect to oil, fats and protein contents. Cottonseed oil is routinely used for cooking and food manufacturing products. Cottonseed oil obtained after proper extraction/processing steps from crude state to refined oil in a variety of ways. Cotton crop is considered for their dual-use purpose, for fiber quality and oil production to promote health benefits in the world. Keeping in view the above facts, this review clearly demonstrated an overview about physicochemical and functional properties of cottonseed oil to promote health benefits associated with the use of this oil. The overall characteristics and all concerned health benefits of CSO will further improve their usefulness is a compact way. We have summarized a brief multi-dimensional features of CSO in all aspects up to the best of our knowledge for the end researchers who can further research in the respective aspect.
\end{abstract}

Keywords: antioxidant activities, cottonseed oil, extraction method, fatty acid composition, health benefits, physicochemical properties.

\begin{abstract}
Resumo
Os óleos vegetais têm propriedades físico-químicas específicas que desempenham um papel vital na dieta nutricional humana em benefício à saúde. O óleo de semente de algodão, utilizado rotineiramente no preparo e na fabricação de alimentos, é obtido através de várias espécies de sementes de algodão, famosas pela alta qualidade de sua fibra., cuja espécie mais utilizada é Gossypium hirsutum. As sementes variam, em relação ao teor do óleo, da gordura e das proteínas, de acordo com o cultivo e as diversas condições agroclimáticas. O óleo de algodão é obtido após etapas adequadas de extração das sementes e processamento do estado bruto ao refinado. Assim, a presente revisão demonstra, de maneira geral, as propriedades físico-químicas e funcionais do óleo de semente de algodão e seus benefícios à saúde humana, resumindo suas características multidimensionais. As características gerais e todos os benefícios do composto podem melhorar ainda mais se utilizadas de forma compacta, auxiliando futuros pesquisadores.
\end{abstract}

Palavras-chave: atividades antioxidantes, óleo de algodão, método de extração, composição de ácidos graxos, benefícios à saúde, propriedades físico-químicas.

\section{Introduction}

Human diet is composed of a basic part of fat/oil. Previous reports of Food and Agriculture Organization (FAO, 2003), revealed that significant increase has been occurred in fat consumption per capita based on average of 53 grams during 1967-1969 to so far as $73 \mathrm{~g} /$ capita/day in 1997-1999 globally that confer $30 \%$ of entire energy supply of humans. Cotton belongs to family Malvaceae and genus Gossypium. Gossypium has different species like G.

*e-mail: amirzia_narc@yahoo.com; sabir.hussain@aiou.edu.pk

Received: September 12, 2020 - Accepted: December 3, 2020 
hirsutum, G. barbadense, G. arboreum and G. herbaceum of profitable significance (Percival et al., 1999; Wendel and Cronn, 2002). Out of these cultivated species, two are tetraploids (G. hirsutum and G. barbadense, $2 n=52$ ), and the remaining two species are diploids i.e. G. arboreum and $G$. herbaceum, $2 n=26$ ). Fiber of cotton is an excellent model which is mainly deal with elongation of plant cell, cell wall and biosynthesis of cellulose (Kim and Triplett, 2001). It has been reported that genus Gossypium consist of about 50 species, out of which 45 species are diploid $(2 n=2 x=26)$ and 5 are tetraploids $(2 n=2 x=52)$. Cotton diploid species include 8 types of genome, indicated by A-G and K genomes respectively (Wendel and Cronn, 2002). It has been further evaluated that A genome of diploids and tetraploids species make spin-able fiber and are cultivated on a small scale, while the $D$ genome species do not possess this character (Applequist et al., 2001). There are variations in genomes size i.e. A, D and $\mathrm{AD}$ genomes, about three fold from $885 \mathrm{Mb}$ in the $\mathrm{D}$ genome to 2,500 $\mathrm{Mb}$ in the tetraploid genome (Hendrix and Stewart, 2005). Globally, a lot of cotton varieties have been developed along with superior yield and production (Van Esbroeck et al., 1999). Gossypium hirsutum is the most important out of all species due to their high cultivation and production of fiber, food and oil on this planet. The cotton plant is cultivated on tropical and subtropical regions of the world like America, Africa, and India. The maximum diversity in wild species of cotton is in Mexico, Australia and Africa respectively.

\section{Cotton taxonomy}

\author{
Kingdom: Plantae \\ Division: Magnoliophyta \\ Class: Magnoliopsida \\ Order: Malvales \\ Family: Malvaceae \\ Genus: Gossypium
}

\section{World cotton and cottonseed oil production}

After soybean, cotton plant is considered as one of the best source of protein and also it is the fifth major oilseed crop after soybean, palm, canola and sunflower (Sawan et al., 2006). The list of commonly used commercial oils is given in Table 1. Cottonseed oil extraction plants are mainly in China, India, Pakistan, the United States, Brazil, and Turkey ( 5 million tonnes per year production. Typically the three main fatty acids in this oil are palmitic acid, oleic acid, and linoleic acid with an average percentage of 22, 20, and 54, respectively (Sekhar and Rao, 2011). Cotton crop is also well-known for their dual-use purpose, one for its fiber producing nature and secondly it contributes about $4 \%$ of vegetable oil production in the world (Ashraf, 2002). In Pakistan, it shares round about 65-70\% in the local edible oil industry (Khan and Hassan, 2011). Their seeds are directly or indirectly used in the food of human and livestock as well (Bertrand et al., 2005; Elangovan et al., 2006). The seeds are a good source of oil (18-25\%) and $20-25 \%$ protein (Saxena et al., 2011). The production of cottonseed oil is varying from country to country, due to which the choice of sale of cottonseed is increased in the international market (Tables 2 and 3).

\section{Value-added products of cotton}

It has been reported that cotton importance is crucial in various food products like shortening, margarine, liquid oils, and other processed fats and oils become important constituents in food products prepared in the home, in restaurants, and by food processors (Gerasimidis et. al., 2007). Hitherto, cottonseed oil was considered as the prime oil source in the United States for all four food product categories. The US vegetable oil industry was developed with cottonseed oil as the original source oil and it dominated this market for almost 100 years. Even though maximum food products are prepared today were developed with a shortening, margarine or an oil product containing cottonseed oil. Disparate of new source oils, cottonseed oil is more widespread source of oil for the running of the preferred functionality for most products. No doubt that cottonseed oil or another $\beta$ - crystal former is essential to produce interpretations with soybean, sunflower, canola and corn oils, to yield a smooth, plastic, and consistency.

Table 1. Commonly used commercial oils.

\begin{tabular}{|c|c|c|c|c|c|c|c|}
\hline & $\begin{array}{c}\% \\
\text { Saturated } \\
\text { fatty } \\
\text { acid }^{*}\end{array}$ & $\begin{array}{c}\text { \% Linolenic } \\
\text { acid (Poly, } \\
\text { Omega-3 } \\
\text { C18:3) }\end{array}$ & $\begin{array}{c}\text { \% Linolenic } \\
\text { acid (Poly, } \\
\text { Omega-6 } \\
\text { C18:2)* }\end{array}$ & $\begin{array}{c}\text { \% Oleic acid } \\
\text { (Mono, } \\
\text { C18:1)* }\end{array}$ & $\begin{array}{l}\text { Hydrogenation for } \\
\text { commercial uses }\end{array}$ & $\begin{array}{l}\text { Smoke } \\
\text { Point* }\end{array}$ & Taste \\
\hline Sunflower Oil & 9 & Trace & 26 & 65 & No & 450 & Clean \\
\hline Corn Oil & 12.7 & 0.7 & 58 & 24.2 & No & 410 & Clean \\
\hline Soybean Oil & 14.4 & 6.8 & 51 & 22.8 & Yes & 450 & Clean \\
\hline Canola Oil & 7.1 & 9.3 & 20.3 & 56.1 & Yes & 435 & Clean \\
\hline Cottonseed Oil & 25.7 & 0.2 & 51.5 & 17.8 & No & 450 & Clean \\
\hline Olive Oil & 13.5 & 0.6 & 7.9 & 72.5 & No & 280 & Distinct \\
\hline
\end{tabular}

Source: USDA Nutrient Database, Release $14\left({ }^{*}\right.$ NSA data from industry sources, 2002) 
Table 2. World cotton production (1,000 bales).

\begin{tabular}{lcccc}
\hline \multicolumn{1}{c}{ Countries } & $\begin{array}{c}\text { Year } \\
\mathbf{2 0 0 7 - 0 8}\end{array}$ & $\begin{array}{c}\text { Year } \\
\mathbf{2 0 0 8 - 0 9}\end{array}$ & $\begin{array}{c}\text { Year } \\
\mathbf{2 0 0 9 - 1 0}\end{array}$ & $\begin{array}{c}\text { Year } \\
\mathbf{2 0 1 0 - 1 1}\end{array}$ \\
\hline China & 37,000 & 36,700 & 32,000 & 30,500 \\
India & 24,000 & 22,600 & 23,000 & 25,400 \\
United States & 19,207 & 12,815 & 12,188 & 18,104 \\
Pakistan & 8,600 & 8,700 & 9,600 & 8,800 \\
Brazil & 7,360 & 5,480 & 5,450 & 8,500 \\
Australia & 640 & 1,500 & 1,775 & 4,200 \\
Uzbekistan & 5,350 & 4,600 & 3,900 & 4,100 \\
Other & 17,519 & 14,686 & 13,471 & 14,985 \\
Total & 119,676 & 107,081 & 101,384 & 114,589 \\
\hline
\end{tabular}

Table 3. World cottonseed oil production (1,000 tonnes).

\begin{tabular}{lcccc}
\hline \multicolumn{1}{c}{ Countries } & $\begin{array}{c}\text { Year } \\
\mathbf{2 0 0 7 - 0 8}\end{array}$ & $\begin{array}{c}\text { Year } \\
\mathbf{2 0 0 8 - 0 9}\end{array}$ & $\begin{array}{c}\text { Year } \\
\mathbf{2 0 0 9 - 1 0}\end{array}$ & $\begin{array}{c}\text { Year } \\
\mathbf{2 0 1 0 - 1 1}\end{array}$ \\
\hline China & 1,625 & 1,600 & 1,466 & 1,389 \\
India & 1,062 & 1,030 & 1,045 & 1,150 \\
Pakistan & 520 & 497 & 540 & 530 \\
Brazil & 380 & 318 & 326 & 460 \\
United States & 389 & 303 & 280 & 377 \\
Uzbekistan & 313 & 249 & 224 & 221 \\
Turkey & 166 & 116 & 93 & 110 \\
Others & 758 & 666 & 661 & 743 \\
Total & 1,625 & 1,600 & 1,466 & 1,389 \\
\hline
\end{tabular}

\section{Cottonseed meal}

To prepare the cotton seed meal the cotton seed is delinted and decorticated. Cottonseed meal has to be in the majority of bound form of gossypol in contrast to whole cottonseed. Once their separation from the hull, the cottonseed meats are moistened, flaked and cooked prior to set on an expander. Then they are extracted (acetone and aqueous acetone extraction Gerasimidis et. al., 2007), desolventized (aqueous acetone) and toasted before being ground into a meal (Jones and King, 1996). Data from various surveys of National Cottonseed Products Association (NCPA) revealed that the free gossypol levels in meal prepared with the method of expander-solvent has been remained very low i.e. less than $0.18 \%$ (Forster Junior and Calhoun, 1995; Park Waldroup, 2000).

\section{Whole cottonseed}

While dealing with whole cottonseed these processes namely roasting, extruding and cracking has enhanced their digestion in certain testing but on the other hand it has also augmented the accessibility of free gossypol in a number of experiments. Particularly in the case of PIMA seed contain a small number of lint fibers attached to prolong their residence time in the rumen (Kirk and Higginbotham, 1999).

\section{Cottonseed oil}

The oxidative stability of cotton seed oil occurs due to their fatty acids profile. Tocopherols which are present in cottonseed oil (CSO) that inhibits rancidity development and hence contribute their stability in the product obtained for long shelf life. CSO is naturally hydrogenated oil and is fit for heart as it contains different fatty acids like palmitic, stearic, oleic, linoleic and linoleinic in enough amounts. Oil of cottonseed has also get significance in preparation of foods because of its high smoke point $\left(232^{\circ} \mathrm{C}\right)$ as compared to other cooking oils and it is quite good to be used for the frying purposes of food items (O'Brien and Wakelyn, 2005). Cottonseed oil is used in the making of biscuits, potato chips, crackers, doughnuts and in ice cream preparation.

\section{Refined cottonseed oil}

Refined Cottonseed oil (CSO) has a soft flavor and golden color. Refined CSO has been used in a lot of other purposes excluding of food items like in the production of biodiesel, in paint industry and has the potential in environmentally accepted lubricant additive to promote the lubricating capabilities of the base oil SAE 20 W50 (Figure 1). In Industrial point of view, refined cottonseed oil contains alkyl resins used for interior paints, unique lubricants and soft soaps (Ertugrul and Filiz, 2004).

\section{Cooking and salad oil sources}

Currently, cooking and salad oils are the only edible fat and oil products with increased consumption numbers. Cottonseed oil was the prime cooking and salad oil utilized at 1950s and on routine basis in the United States. CSO has lost its supremacy being used in shortenings and margarines in the early 1950s, however it remained the favorite liquid oil because of flavor trouble linked with soybean oil. Later, their demand was decreased as a source of salad and cooking oil in the market due to the reason that the problems associated with flavor of soybean oil has been recovered with advancement in technology. Exports of CSO helped to sustain the best pricing in the market locally. The main use of liquid CSO in the United States is as cooking oil to get snack foods. The exclusive CSO taste convey a pleasant, steady flavor to potato chips and other salty snacks unfeasible by means of other frying oils that require the nutty fried flavor note.

\section{Cottonseed meal as organic fertilizer}

The cottonseed meal can be used as organic fertilizer when dried because it includes about $41 \%$ protein and have some other nutrients like fatty acids (omega-9). It has the potential to be mixed with other natural fertilizers to advance their dominance as well. Owing to their natural 


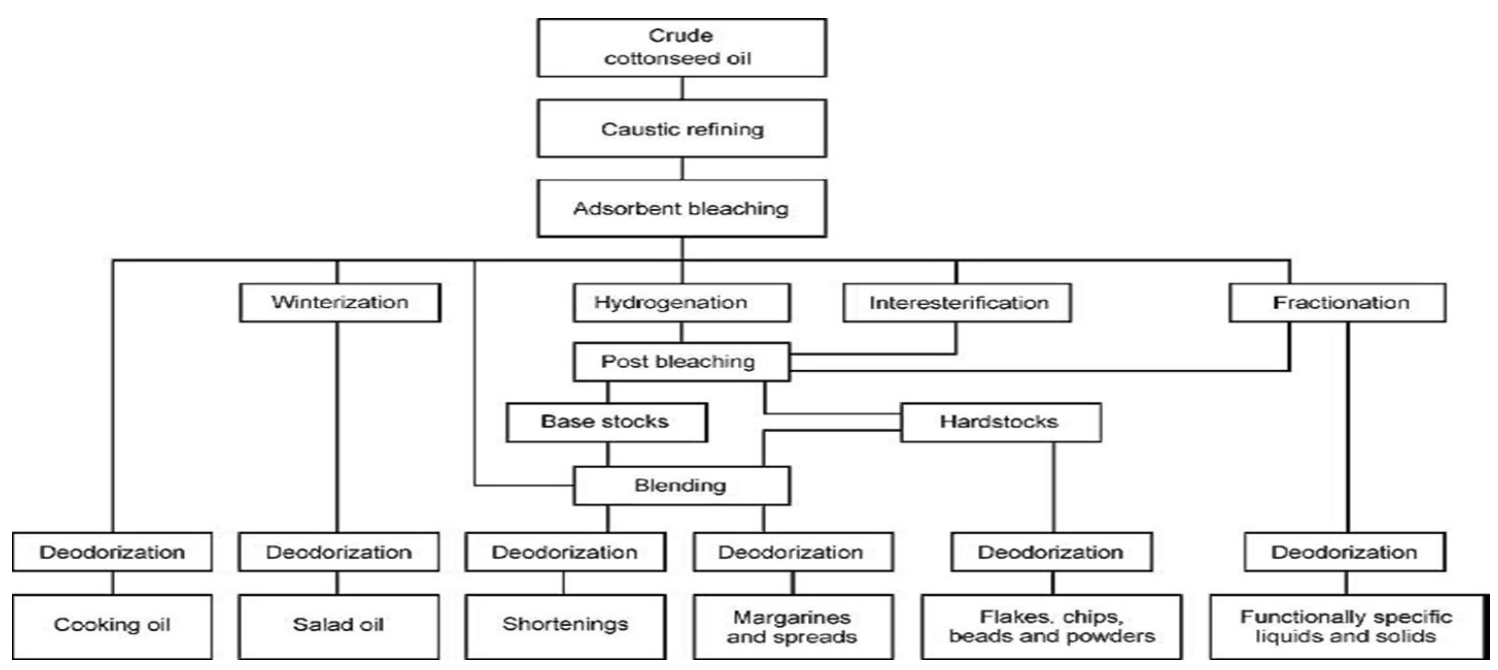

Figure 1. Overview of cottonseed oil.

nutrients, cottonseed meal has been applied to improve soil quality and facilitate to keep moisture level constant. Due to this property it provides as an excellent source of natural fertilizers in dry areas. Cottonseed meal fertilizers can be used for roses, camellias, or vegetable gardens.

\section{Cottonseed oil extraction methods}

CSO is cooking oil extracted from the delinted and decorticated cottonseed. The purified cottonseed initially being passed from a chain of pressure rolls to make slim flakes, then after that flakes are passed from steam pressure, due to which oil cells are ruptured. Later on, the flakes are moreover compressed in hydraulic presses. Besides hydraulic pressing, they are processed in constant screw-type expeller that eliminates oil at high pressure. There are different methods available for oil extraction from seeds. The most common methods are discussed in details for cottonseed oil extraction.

\subsection{Solvent extraction method}

Solvent extraction method is widely used for oil extraction from seeds but in case of soybean oil its use is not up to a larger extent. It is studied that normal yield of cottonseed oil is about $16-17 \%$. In this method, crude oil is treated to obtain refined scores (grade). After that it involves alkali refining for the removal of impurities, the next step is bleaching with activated clays and at last vacuum steaming to eliminate traces of odour (Encyclopaedia Americana International, 2001). Cottonseed is used for various purposes but production of oil has its own importance in daily life. Crude cottonseed oil is processed prior to use in the food products. The first step in this process is refining. During refining step, dark colors materials are removed and clear yellow oil appear at the end in this process. A lot of solvents and their mixtures have been reported in literature like heptane, acetone, ethanol-water azeotrope, methyl-pentane, isohexane, petroleum-ether, trichloroethane, chlorinated hydrocarbons, alcohols for oil extraction from different oilseeds including cotton (Conkerton et al., 1995; Wan et al., 1995a; Gandhi et al., 2003; Liauw et al., 2008; Kuk et al., 2005; Sayyar et al., 2009). The best method out of all these is the use of alcohols because of their high threshold limit in the environment. Feng (2010) has mentioned that simultaneous extraction of cottonseed oil and gossypol by using mixture of methanol and hexane thus reducing gossypol to $0.014 \%$ and hence making the cottonseed cake fit for feed.

\subsection{Hydraulic pressing}

Cottonseed oil extraction through hydraulic pressing was started in nineteenth century. Hydraulic pressing was the prime source used for the separation of oil from cottonseed. As cotton spinning, weaving, and ginning operations improved during the eighteenth century and more cottonseed became available for crushing, the laborintensive hydraulic press operation quickly yielded to the continuous screw press in the early 1900s. As edible oil increased market worth and equally hydraulic and screw press left about $20 \%$ of the existing oil in the press cake. Later on, research was started to discover a suitable solvent for the extraction of oil remaining in the cake. This attempt led to the pre-press solvent extraction process in the 1930s. Due to the discovery of this mutual combination of mechanical and solvent extraction press cake recovered about $97 \%$ of the available oil in the cottonseed. Extra productivity in terms of oil quality got expander-solvent extraction of cottonseed oil extreme business in the 1970s. Still so far, cottonseed is processed through these 3 processes (screw press extraction, pre-press solvent extraction and expandersolvent extraction) in different parts of the world. The ideal process for cottonseed fluctuates from region to region inside a country (O'Brien and Wan 2001). Hydraulic press oil mills remained up to 1950s and then it was replaced with continuous screw presses and continuous solvent extraction plants, as these required few labors and has the capacity to work at superior rates. 


\subsection{Extraction of cottonseed oil using subcritical water technology}

In this method of cottonseed oil extraction through subcritical water, the efficiencies of extraction ranges at a limit of temperature $180-280^{\circ} \mathrm{C}$. The average size of particle varies from $3 \mathrm{~mm}$ to less than $0.5 \mathrm{~mm}$, whereas the ratios of water: seed $(0.5: 1,1: 1$, and $2: 1)$ and time of extraction fall in the range of 5-60 min were maintained. The extracted cottonseed oil composition through subcritical water, was further examined by using gas-liquid chromatography and compared with that extracted using traditional hexane extraction. The optimized protocol through subcritical water method revealed that the extracted cottonseed oil was the same as that of traditional method of extraction through hexane (Abdelmoez et al., 2011).

\subsection{Microwave-assisted extraction}

This is a new method of cottonseed oil extraction which has the potential to decrease the extraction time and solvent consumption. Through Microwave-assisted extraction (MAE), the main focus was aimed on oxidative stability and physicochemical properties of cottonseed oil. According to the findings of Taghvaei et al., 2014 the best extraction conditions include irradiation time for $3.57 \mathrm{~min}$; moisture content of cottonseed was $14 \%$ and cottonseed to solvent ratio $1: 4$, due to this process the extraction effectiveness reached up to $32.6 \%$, while other contents like total phenolics $46 \mathrm{ppm}$, free fatty acids $0.7 \%$, peroxide value of 0.2 and $11.5 \mathrm{~h}$ of Rancimat oxidative stability at $110 \mathrm{C}$. MAE cottonseed oil was determined through GC analysis and their results showed that palmitic acid (23.6\%), stearic acid (2.3\%), oleic acid (15.6\%) and linoleic acid (55.1\%), were not significant as compared to control cottonseed oil as extracted through conventional method. MAE oil samples obtained from the whole cottonseed possesses long-term stability, as compared to oil samples having BHT (Taghvaei et al., 2014).

MAE is a new method that has been studied extensively by many researchers (Camel, 2000; Amarni \& Kadi, 2010). The effectiveness of MAE process depends on the time and temperature of extraction, sample ratio and nature of both the solvent and the solid matrix (Terigar et al., 2010). Reports are available that microwaves demolish cell and tissue structures in plant like oilseeds resulting in better extraction. The reason is that as heat produced due to the movement of the polar molecules, and thus the cellular proteins are denatured (Chemat et al., 2005; Azadmard-Damirchi et al., 2010). It has been well studied that moisture of oilseeds (cotton) before extraction play a vital role in extraction efficiency. The oil of cottonseed contains $30 \%$ of saturated fatty acids which is stable and is consumed mainly as frying oil formulations (Shahidi, 2005). Therefore, it is subjected more often to high temperatures and moisture during frying. It has been observed that food moisture content, oxygen and high temperatures have caused a variety of chemical changes and loss of antioxidants like steam distillation of antioxidants, oxidation of phenolic compounds, reduction of their prooxidative activity due to reaction with fried materials and polymerisation (Pokorny et al., 2000).

\section{Physicochemical characteristics of cottonseed oil}

Crude cottonseed oil is mainly derived from two species of cotton i.e. G. hirsutum and G. barbadense due to its unique properties like flavor, dark reddish brown color of their seed. Cottonseed oil has the presence of C16 and C18 fatty acids due to which it has no more than 2 double bonds the cotton oil contains about $50 \%$ polyunsaturated fatty acids, mainly linoleic acid. Therefore, this crude oil has less oxidative stability than olive oil, palm oil, peanuts oil, rapeseeds oil and others. Various factors affecting variation in cottonseed oil mainly includes soil, fertilizer, genotype and environmental conditions (Cherry, 1983; Jones and King, 1996).

Physical as well as chemical properties of fats and oils are mainly determined by fatty acids that they possess and their position within the triacylglycerol molecule (Table 4). Chemically, all fats and oils are esters of glycerol and fatty acids. However, physical properties of natural fats and oils are extensively different. This is because (i) the ratio of the fatty acids differs more than broad range, and (ii) the structures of triacylglycerol vary for each individual oil and fat. Commonly fats and oils are termed as triacylglycerols (triglycerides) as the glycerol molecule has three hydroxyl groups where a fatty acid can be attached. In addition, all triacylglycerols have similar glycerol unit, thus the different properties is contributed due to fatty acids. The following three reasons are accompanied for the variation in fatty acid components; (i) chain length, (ii) the number and position of the double bonds, and (iii) the position of the fatty acids within the glycerol molecule. So any change in these characters is applied for differences in the chemical and physical properties practiced with edible fats and oils.

\section{Cottonseed oil fatty acid composition}

Cottonseed oil profile of fatty acid is representative of the oleic-linoleic cluster of vegetable oils, as these two unsaturated fatty acids composed of just about $75 \%$ of the total fatty acids (Figure $2 \& 3$ ). Furthermore, their

Table 4. Typical refined cottonseed oil analytical characteristics.

\begin{tabular}{lcc}
\hline \multicolumn{1}{c}{ Characteristics } & Typical & Range \\
\hline Specific gravity g/cc at $25 / 25^{\circ} \mathrm{C}$ & & $0.916-0.918$ \\
Refractive index at $25^{\circ} \mathrm{C}$ & & $1.468-1.472$ \\
Iodine value & 110.7 & $99.0-113.0$ \\
Saponification number & & $189-198$ \\
Unsaponifiable matter $(\%)$ & & $0.5-0.7$ \\
Titer $\left({ }^{\circ} \mathrm{C}\right)$ & $30.0-37.0$ \\
Melting point $\left({ }^{\circ} \mathrm{C}\right)$ & & $10.0-16.0$ \\
Cloud point $\left({ }^{\circ} \mathrm{C}\right)$ & & $-1.1-3.3$ \\
Pour point $\left({ }^{\circ} \mathrm{C}\right)$ & & $-3.9-0$ \\
Cold test $(\mathrm{h})$ & & - \\
${ }^{*}$ AOM stability $(\mathrm{h})$ & 0 & - \\
\hline
\end{tabular}

*Active Oxygen Method. 

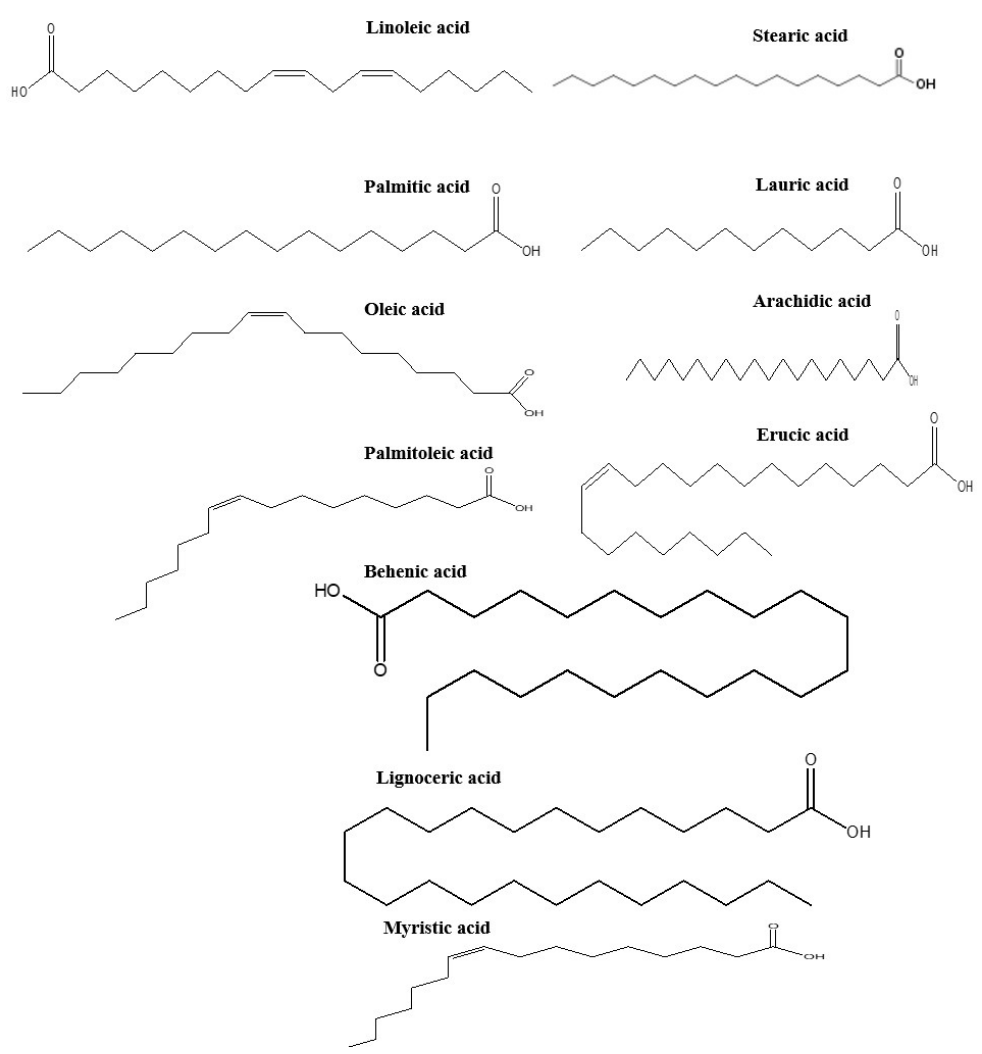

Figure 2. Functional compounds present in cottonseed oil (Firestone, 1999).

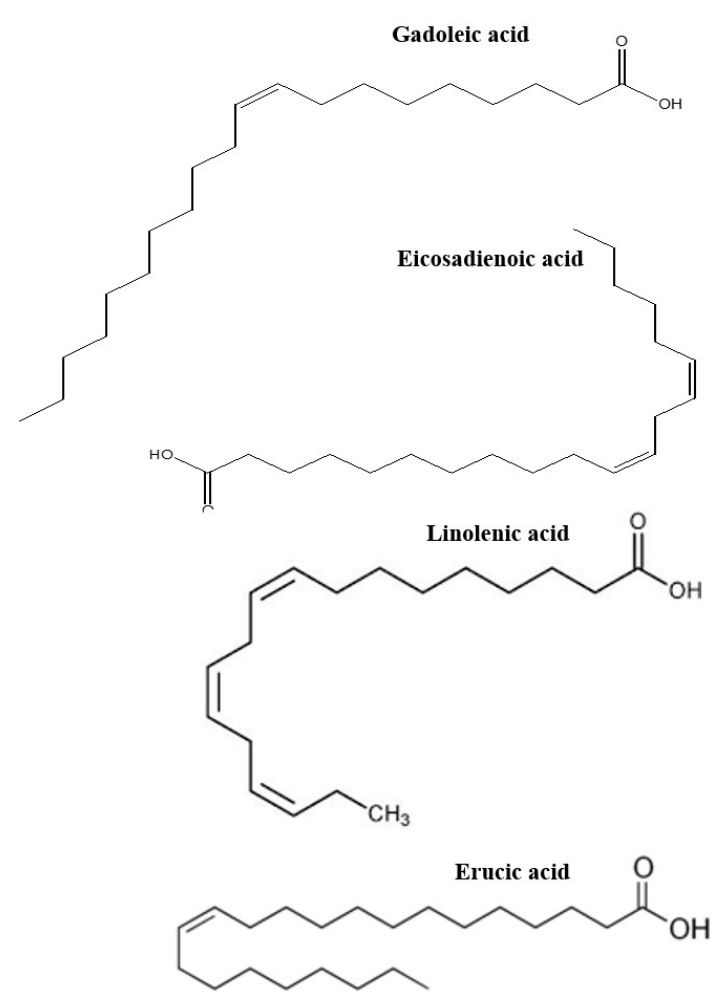

Figure 3. Functional compounds namely Gadoleic acid, Eicosadienoic acid, Linolenic acid and Erucic acid present in cottonseed oil (Firestone, 1999). individual contribution is round about $22 \%$ of oleic, while linoleic makes up 52\% and linolenic acid is commonly less than $1 \%$. Palmitic acid, a saturated fatty acid usually associated with $\beta$-crystals, makes up around $24 \%$ of the total (Zhong et al., 2013). On the other hand, very trace amount of other saturated fatty acids like stearic and myristic, are being detected in typical cottonseed oils. It has been reported by Bailey (1948) that upland cottonseed oils composition will hardly fall outside of these ranges i.e. total saturated fatty acids $23-28 \%$, oleic acid $22-28 \%$ and $44-53 \%$ of linoleic acid. The acceptable range of fatty acids prescribed by Codex in 1997 for cottonseed oil is shown in Table 5 (Firestone, 1999). It has been noted that both factors play a significant effect on oil quantity. The oil content of moisture and lint-free seeds ranged from $23.2 \%$ to $25.7 \%$ depending on location. Significant variation in cottonseed oil was found in the key six fatty acids inside cultivars and location. Out of all, five of them have significant interactions between cultivar and location. Variation was observed in linoleic acid ranged from $49.07 \%$ to $57.64 \%$. Similarly, Palmitic acid falls in the range of $21.63 \%$ for Acala variety grown in Lubbock to $26.18 \%$ for a Lockett variety grown in Corpus Christi. It has been studied that agronomic practices and weather conditions for a locality may play role due to observed variation. Variations in oil quantity are not well studied in cotton, further work is required in this dimension. 
Table 5. Codex fatty acid ranges for cottonseed oil.

\begin{tabular}{lccc}
\hline \multicolumn{1}{c}{ Fatty acids } & \% & Typical & Range \\
\hline Lauric & $\mathrm{C} 12: 0$ & & $0-0.2$ \\
Myristic & $\mathrm{C} 14: 0$ & 0.7 & $0.6-1.0$ \\
Palmitic & $\mathrm{C} 16: 0$ & 21.6 & $21.4-26.4$ \\
Palmitoleic & $\mathrm{C} 16: 1$ & 0.6 & $0-1.2$ \\
Stearic & $\mathrm{C} 18: 0$ & 2.6 & $2.1-3.3$ \\
Oleic & $\mathrm{C} 18: 1$ & 18.6 & $14.7-21.7$ \\
Linoleic & $\mathrm{C} 18: 2$ & 54.4 & $46.7-58.3$ \\
Linolenic & $\mathrm{C} 18: 3$ & 0.7 & $0-0.4$ \\
Arachidic & $\mathrm{C} 20: 0$ & 0.3 & $0.2-0.5$ \\
Gadoleic & $\mathrm{C} 20: 1$ & & $0-0.1$ \\
Eicosadienoic & $\mathrm{C} 20: 2$ & & $0-0.1$ \\
Behenic & $\mathrm{C} 22: 0$ & 0.2 & $0-0.6$ \\
Erucic & $\mathrm{C} 22: 1$ & & $0-0.3$ \\
Docosadienoic & $\mathrm{C} 22: 2$ & & $0-0.1$ \\
Lignoceric & $\mathrm{C} 24: 0$ & & $0-0.1$ \\
\hline
\end{tabular}

Source: Firestone (1999).

\section{Cyclopropenoid fatty acids}

Cottonseed oil contains up to $0.5 \%$ of a pair of unique fatty acids: malvalic (18:1) and sterculic (19:1). These acids are characterized by the presence of a cyclopropene group at or near the center of the fatty acid chain (Table 6). In proper conditions these give colored compounds and the development of a red color in the Halphen test (reaction with sulfur in carbon disulfide in the presence of amyl alcohol) is due to the cyclopropene acids and therefore characteristic of cottonseed oil (and other minor oils containing cyclopropene acids). This test was developed during 1897 for cottonseed oil. Furthermore, the presence of cyclopropenoid acids in animal diets produces unwanted physiological effects like egg production reduced, poor hatching, and pink egg whites in chickens, and in rats, decreased growth and sexual development and carcinogenic properties. Through conventional processing method, specially hydrogenation and deodorization, mostly inactivate these acids. In such circumstances their level is reduced from 0.53 to $0.04 \%$ by deodorization (Jones and King 1996; O’Brien et al., 2000).

Malvalic and sterculic acids are 17 and 18 carbons long and contain one double bond at the site of the propene ring, either at the 9,10 position or 8,9 position. The cyclopropene ring is the physiologically active entity of the two fatty acids (Palis and Irvine, 1985; Melcer et al., 1987). The physiological activity of sterculic acid is reported to be greater than that of malvalic acid. The ratio of malvalic acid to sterculic acid in cottonseed oil is usually about 3 to 1 . The cyclopropenyl structure is highly strained, which apparently accounts for its reactivity (Lo et al., 1985). Due to this activity, it makes it very prone to the inactivation that regularly occurs during processing. In CSO, the CPFAs are reduced in processing as a result cottonseed oil in commercial stations comprises a negligible level.

\section{Triacylglycerol composition}

The structure of triacylglycerol of an edible fat or oil is affected by the fatty acids present and the point of attachment of each acyl chain to the glycerol (Table 7). Triacylglycerols with three identical fatty acids are called monoacid triacylglycerols. Triacylglycerols having more than one type of fatty acid are called mixed triacylglycerols. A mixed triacylglycerol holding 3 different fatty acids has three regioisomeric forms and six stereoisomeric forms, depending on which fatty acid is in the middle, $s n-2$, or $\beta$-position of the glycerol portion of the molecule and which fatty acids are in the $\alpha$ or outer positions ( $s n-1$ and $s n-3)$. The arrangement of the fatty acids in cottonseed oil is considered to be nonrandom, with the saturated fatty acids positioned predominately in the $s n-1$ and/or $s n-3$ positions and the unsaturated fatty acids in the $\beta$ or $s n-2$ position. Since linoleic, oleic and palmitic fatty acids account for over $90 \%$ of cottonseed oil's fatty acid composition, most of the triacylglycerols contain some combination of these fatty acids (Bland et al., 1991). Investigation of CSO through semi-quantitative thin layer chromatography showed that the distribution of saturated (S) and unsaturated fatty acids (U) in the 1, 2, and 3 acyl positions were: $11.8 \%$ SUS, 4.4\% SSU, $12.3 \%$ USU, and $42 \%$ UUS. Almost $30 \%$ of the triacylglycerols contain only unsaturated fatty acids but no molecules are completely saturated (Jones and King 1996). In another study conducted by Lisa and Holcapek (2008) that approximately $97 \%$ of triacylglycerols are composed of palmitic (22\%), oleic (18\%) and linoleic (57\%) acids. The composition in triacylglycerol species is characterized by the presence of $\operatorname{LLP}(29 \%)$, LLL (17\%), OLL (14\%), OLP (12\%), and PLP (8\%) (Lisa and Holcapek, 2008).

\section{Cottonseed oil nonglyceride components}

The prime ingredients in crude vegetable oils are the triglycerides, apart from this they also comprise of variable amounts of nonglyceride constituents. CSO is scarce for the quantity and variety of nonoil elements in the crude oil. Its content of nonglyceride substances, exclusive of free fatty acids, normally amounts to $2 \%$ or more in the crude state. These minor components, known as the unsaponifiable fraction, contain of phospholipids, tocopherols, sterols, resins, carbohydrates, pesticides, gossypol and other pigments. Some, but not all, of the nonglyceride materials are undesirable. Therefore, the objective in all edible oil processing is to remove the objectionable impurities with the least possible damage to the desirable constituents.

\subsection{Gossypol}

Cottonseed oil is different from other commercially key fats and oils due to the existence of a relatively intricate system of pigments (Table 8 ). Most of the pigments are of the gossypol type, a biologically active terpenoid substance exist in discreet glands in the seed, leaf, bract, stem, taproot, bark, and root of the cotton plant. The adaptive function of the compound is believed to be insect resistance. There are 15 gossypol pigments or derivatives have been identified in cotton plant products (Berardi and 
Table 6. Cottonseed oil cyclopropenoid fatty acid levels.

\begin{tabular}{|c|c|c|c|c|}
\hline Cottonseed oil source & Malvalic acid & Sterculic acid & Total & Reference \\
\hline Crude oil & 0.52 & & & Harris et al. (1964) \\
\hline Crude oil & $0.56-0.90$ & & & Harris et al. (1964) \\
\hline Crude oil & $0.58-0.98$ & & & Bailey et al. (1966) \\
\hline Crude oil & $0.7-1.5$ & $0.3-0.5$ & & Shenstone and Vickery (1961) \\
\hline Crude oil & $0.22-1.44$ & $0.08-0.56$ & $0.3-2.0$ & Phelps et al. (1965) \\
\hline Crude oil & 0.64 & & & Harris et al. (1964) \\
\hline Refined oil & 0.62 & & & Harris et al. (1964) \\
\hline RBD oil & $0.015-0.324$ & $0.005-0.126$ & $0.02-0.45$ & Phelps et al. (1965) \\
\hline RBD oil & 0.04 & & 0.04 & Eaves et al. (1968) \\
\hline Salad oil & $0.04-0.42$ & & & Harris et al. (1964) \\
\hline Salad oil & $0.1-0.23$ & & & Frampton et al. (1966) \\
\hline
\end{tabular}

Table 7. Triacylglycerol (TAG) composition (\%)*

\begin{tabular}{lcc}
\hline \multicolumn{1}{c}{ Triacylglycerol } & Gas chromatography (GC) & $\begin{array}{c}\text { High-performance liquid } \\
\text { chromatography (HPLC) }\end{array}$ \\
\hline Palmitic-linoleic-linoleic & 25.7 & 27.5 \\
Linoleic-linoleic-linoleic & 16.1 & 19.0 \\
Palmitic-oleic-linoleic & 14.0 & 14.0 \\
Oleic-linoleic-linoleic & 12.9 & 12.5 \\
Palmitic-palmitic-linoleic & 8.7 & 7.1 \\
Oleic-oleic-linoleic & 4.4 & 3.1 \\
Palmitic-oleic-oleic & 3.3 & 3.1 \\
Palmitic-palmitic-oleic & 2.5 & 2.2 \\
Oleic-oleic-oleic & 2.4 & 1.6 \\
Stearic-linoleic-linoleic & 2.4 & 1.4 \\
Stearic-palmitic-linoleic & 2.1 & 1.5 \\
Stearic-oleic-linoleic & 1.5 & 1.3 \\
\hline
\end{tabular}

"The figures relate to all regioisomers and stereoisomers containing the three fatty acids indicated.

Table 8. Analysis of treated cottonseed meal.

\begin{tabular}{|c|c|c|c|c|c|c|}
\hline Gossypol (\%) & \multirow{2}{*}{$\mathbf{T}$} & \multirow{2}{*}{$\mathbf{F}$} & \multirow{2}{*}{ B } & \multirow{2}{*}{$\begin{array}{c}\text { Protein } \\
\%\end{array}$} & \multirow{2}{*}{$\begin{array}{c}\text { N-Sol } \\
\%\end{array}$} & \multirow{2}{*}{ Avail-lys } \\
\hline Treatments & & & & & & \\
\hline Untreated cottonseed meal & 1.38 & 0.74 & 0.64 & 48.12 & 79.4 & 2.68 \\
\hline Mod. Alk. Peroxidase & 0.07 & 0.00 & 0.07 & 49.4 & 21.6 & 1.54 \\
\hline Acetic acid & 0.31 & 0.03 & 0.28 & 49.0 & 84.6 & 2.78 \\
\hline Azeotrope & 0.28 & 0.03 & 0.25 & 48.7 & 83.3 & 2.74 \\
\hline Azeot: acetic acid & 0.22 & 0.02 & 0.20 & 46.1 & 83.8 & 3.04 \\
\hline Azeot: Am nitrate & 0.27 & 0.05 & 0.22 & 47.3 & 81.3 & 2.44 \\
\hline Azeot: Am hyd. & 0.19 & 0.01 & 0.18 & 46.8 & 87.4 & 3.09 \\
\hline Ethanolamine & 0.08 & 0.03 & 0.05 & 45.7 & 81.7 & 2.69 \\
\hline
\end{tabular}

T: Total gossypol F: Free gossypol B: Bound gossypol. Source: Harris et al. (2009).

Goldblatt, 1980). Out of these, the most dominating pigment is polyphenolic binaphthyl aldehyde, which is yellow in color and referred to as gossypol (Calhoun, et al., 1991). The level of gossypol in cotton whole seed is around $0.6 \%$ by weight or $6000 \mathrm{ppm}$. These glands are biologically active in intact form (not ruptured), and this is actually called as 
"free" form. It has been documented that large amounts of gossypol is toxic when fed to livestock, particularly in its free form. Their amounts can be variable due to the factors affecting i.e. duration of feeding, species, breed and age, state of rumen development; feeding level; and method of feeding (Calhoun et al. 1991). There are considerable variations observed in sensitivity of animals to gossypol in between species and classes of animals. It has been observed that monogastric animal and ruminants are more vulnerable to gossypol poisoning than mature ruminants (Abou-Donia, 1976; Berardi and Goldblatt, 1980). It is confirmed that lysine bound to gossypol (Baliga and Lyman, 1957). Furthermore, bound gossypol is usually unavailable to the animal while some reports showed that bound gossypol caused toxicity but very minute evidence reported to include it along with free gossypol (Jones, 1991). The entire processed content of CSO is not affected by processing; it is equivalent to the sum of the free plus the bound gossypol (Berardi and Goldblatt, 1980). Although, when oil is extracted from the seed, some part of the gossypol is detached with the oil whereas the outstanding gossypol remains with the meal. Studies have showed that alkali-refining and bleaching decrease the gossypol content of CSO to less than $1 \mathrm{ppm}$ from $0.05-0.42 \%$ in solvent-extracted oil and from $0.25-0.47 \%$ in screw-pressed oil (Jones and King, 1996).

\subsection{Phospholipids}

Phospholipids considered as phosphatides to the oil processors, composed of minor quantities of carbohydrates and resins, are commonly denoted as 'gums' that showed negative effects on quality and refined oil yield. It is well known that phospholipids are emulsifiers due to which they hamper the process of separation of oil and water phases in the caustic-refining. The phospholipids are largely divided into hydratable and non-hydratable forms. The first one can be removed by the action with water but the non-hydratable compounds, which are salts or mixed compounds of calcium and magnesium, mainly through phosphatidic acid, solely be reduced insoluble in the oil by using chemical like phosphoric acid. It has been determined that from total phosphorus, phospholipid content calculated by measuring phosphorus molecular weight to the mean molecular weight of the phospholipids in the oil. Usually, the quantity of phospholipids in cottonseed crude oil differs from $0.7-0.9 \%$. Furthermore, the useful effects of phospholipids observed that they act as synergists for the tocopherols which prevent autoxidation of vegetable oils. Due to effect of synergistic, it is relatively accountable for the oxidative firmness of crude cottonseed oil (Jones and King 1996).

\subsection{Tocopherols}

In cottonseed there are present several tocopherol isomers that behave as naturally occurring antioxidants. It is well observed that seven forms of nature's fat soluble antioxidants are present out of which alpha-, beta-, delta-, and gamma-tocopherol play leading in vegetable oils. Alpha-tocopherol take part in Vitamin E function and also play role in somewhat oxidation resistance, while on the other hand gamma and delta forms are considered as the most operative antioxidants. Usually, crude cottonseed oil comprises of 1000-ppm tocopherols, however during processing their third portion can be lost. There are gradual reduction occurs in each stage of processing in tocopherol content most prominently during chemical refining and deodorization methods of processing. Other processes like caustic refining have the potential to eliminate up to 10 to $20 \%$ of tocopherols while 30 to $60 \%$ of the residual natural antioxidants can be removed through deodorization (Teah and Ong, 1986). It was also noticed that maximum loss of tocopherols effect in a severe decline in their defensive control against future oxidation (Hoffmann, 1989).

\subsection{Sterols}

The characteristic features of sterols that they are crystalline in nature, neutral, unsaponifiable, high-melting alcohols and having multiple-ring structures. In natural fats and oils minute amount of sterols are present and the main ingredients of the unsaponifiable substance resides in processed vegetable oils while the rest comprise principally of saturated and unsaturated hydrocarbons. On the other hand, other properties of sterols that they are colorless, heat labile, and quite inert due to which sterols not contributing any key role in property to a fat or oil. Up to some extent part of sterols can be removed through chemical refining method but to obtain maximum efficiency of their separation needs fractional crystallization, molecular distillation, or high-temperature steam distillation. In a finding by comparing caustic-refined cottonseed oil with deodorized cottonseed salad oil, revealed that decrease of total sterols occurs in the range of 0.574 to $0.397 \mathrm{mg} / 100 \mathrm{~g}$ of oil (Norcia and Rosenthal, 1996). Sterols recovered from the processing of byproducts of oil are considered as initial materials for the synthesis of sex hormones and also help to prepare synthetic vitamin D. Vegetable oils sterols are mixtures known as phytosterols. The sterols in most vegetable oils include beta-sitosterol, campesterol, stigmasterol, and others in lesser amounts. Cholesterol is considered as the most widely explored and well known to consumer. Trace amounts of cholesterol have been found in some vegetable oils, but animal fats like tallow are routinely found to contain $1077 \mathrm{mg} / \mathrm{kg}$ (Pennington and Bowes, 1994). Sterols are known to have a wide range of biological activities and physical properties. Numerous phytosterols with specific structures are recognized to prevent oxidative deterioration of oils helping as possible anti-polymerization mediators for frying oils (Abidi 2001). Various factors affecting the loss of phytosterols like adsorption, partitioning and oxidation. Dehydration can also happens which results in the formation of stearadienes (Leone et al., 1984; Ferraei,et al., 1989; Zunin, et al., 1989; Grob, et al., 1992; Ferrari et al., 1997).

\subsection{Trace metals}

Trace metals are present in vegetable oil like cottonseed oil in a different manner depending on oils of plant, extraction and processing methods. Although they are present in a very minute amount but still they reduce the efficacy of processing because of their hazardous effects 
on quality of product and subsequently on human health. Trace quantities of copper, iron, manganese, and nickel substantially reduce the oxidative stability of oils while calcium, sodium, and magnesium reduce the efficiency of refining, bleaching, and hydrogenation systems. It has been studied that the effects of the metals can be reduced by the use of chelating agents at several process points to isolate the trace metals (Flider and Orthoefer, 1981). For this purpose, citric and phosphoric acids are mostly used.

\section{Genetically modified cottonseed oil}

Genetic engineering tools along with plant breeding techniques can provide prevailing way to modify and improve oilseeds composition in terms of nutritional value and their subsequent functional properties essential for numerous applications of oil used in food preparation. It has been reported that main modifications in oilseeds fatty acids composition by various ways like conventional plant breeding, biotechnology tools like post-transcriptional gene silencing and up to some extent through induced mutation. Specific attention has been paid to develop a number of high-oleic oils for their efficient stability used in cooking. GM oils offer the chance to substitute the recent extensive use of saturated fats and hydrogenated oils that give ominously to improve hazard of cardiovascular disease due of the influence of saturated and trans fatty acids on elevating LDL cholesterol in the bloodstream. Likewise, oils with improved stearic acid content established to assist the making of solid fats deprived of the necessity for hydrogenation.

According to the findings of Liu et al. (2002a) in which they applied hpRNA mediated PTGS in cotton to downregulate main fatty acid desaturase genes and develop nutritionally-improved high-oleic (HO) and high-stearic (HS) cottonseed oils (CSOs). Through biotechnological approach of ghFAD2-112-desaturase gene silencing elevated oleic acid content from $13 \%$ to $78 \%$ and silencing of the ghSAD-19-desaturase gene significantly improved stearic acid from $2 \%$ (their normal level) to $40 \%$. Moreover, palmitic acid was ominously dropped from $26 \%$ to $15 \%$ in both HO and HS lines. Cottonseed oil is considered as esteemed raw material in the food industry due to its optimum level of the saturated palmitic acid and absence of the unstable linolenic acid that convey worthy firmness and aroma properties. Though, CSO is frequently hydrogenated to reduce the level of polyunsaturates and attain great stability essential for deep-frying or the solidity required for margarine hard stock. Therefore, partially hydrogenated CSO covers a relatively higher level of nutritionally undesirable saturated and trans fatty acids. Through modification and improvement of genetic engineering tools the CSO fatty acid composition is hence essential to escape the requirement for hydrogenation and thus to increase the nutritive value products of CSO. One of the main drawback that inadequate genetic variation in cotton seed fatty acid composition exists due to which it is very responsive to prompted mutation techniques. Likewise, genetic transformation of cotton is not efficient as compared to other oilseed crops. To get rid of these restrictions, now very efficient application of hpRNAmediated gene silencing to gain innovative CSOs rich in either oleic acid or stearic acid while palmitic acid levels has been reduced (Liu et al., 2000).

It has been reported that genetic modifications were accomplished by silencing of two seed-specific genes encoding the key fatty acid desaturase enzymes determining the fatty acid composition of CSO, namely stearoyl-ACP 9-desaturase and oleoyl-PC 12-desaturase (also known as 6-desaturase). Numerous candidate genes were cloned from cDNA library of cottonseed for these enzymes for these enzymes on the basis of their estimated homology to the already sequenced 9-desaturase gene from castor bean and the12-desaturase gene from Arabidopsis thaliana. Based on expression analysis of candidate sequences exposed that specific genes that were accountable for these enzymes activity in the developing seed, namely the 9-desaturase gene ghSAD-1 (Liu et al., 1996) and the 12-desaturase gene ghFAD2-1 respectively (Liu et al., 1999). Similarly, inverted-repeat constructs encoding hpRNA directed contrary to any ghSAD-1 or ghFAD2-1and motivated by the seed-specific soybean lectin promoter were subsequently transformed to in vitro responsive variety of cotton Coker 315. Through silencing of ghFAD2-1expression enhanced oleic acid levels in transgenic lines mature seeds i.e. $78 \%$ oleic acid as compared to control (non-transformed) 13\% oleic acid. Likewise, silencing of the ghSAD-1gene gave optimum stearic acid levels (40\%) in transgenic lines of cotton as compared to control plants (2\%). In a similar fashion, variations in fatty acid composition were detected through antisense construct targeted contrary to the same genes, but their transformation frequencies were lower than that of hpRNA-encoding constructs. Another positive aspect of this finding that the content of palmitic acid in both high-stearic and high-oleic lines was ominously lowered from $26 \%$ to $15 \%$. As it has been estimated that these fluctuations in fatty acid composition verified as heritable having similar extreme contours being existing in the descendants of the transgenic lines (Liu et al., 2002b).

\section{Health benefits of cottonseed oil}

\subsection{Cottonseed oil and cardiovascular diseases}

According to scientific research on animal shows that cholesterol level reduced through the use of dietary cottonseed oil (CSO) though, in another experiment of CSO-rich diet on humans have been assessed. In this experiment, thirty-eight healthy adults (aged 18-40; 12 males, 26 females) used up a CSO rich diet (95 g CSO daily) for one week. Data revealed that total cholesterol and LDL were reduced (TC Pre: $4.39 \pm 0.9 \mathrm{mmol} / \mathrm{L}$; Post: $4.16 \pm 0.8 \mathrm{mmol} / \mathrm{L}$; LDL Pre: $2.70 \pm 0.8 \mathrm{mmol} / \mathrm{L}$; Post: $2.47 \pm 0.6 \mathrm{mmol} / \mathrm{L})$. furthermore, feeding of a high fat, CSO-rich diet for one week lowered total cholesterol (TC) in tested female contributors deprived of decreasing HDL level. (Davis et al., 2012). It has been investigated that hypercholesterolemia mainly rises in LDL-cholesterol level that obviously linked with increased hazard for 
cardiovascular disease (Carson et al. 2005). To prevent hypercholesterolemia various strategies are applied like modification of body mass index (BMI), composition of diet, and routine life style have played vital roles. Previous findings suggest discrepancy role of oil and fat types in diet and their subsequent effects on plasma total cholesterol and its components (HDL and LDL) (Harris et al. 2009; Eckel et al. 2007; Fletcher et al. 2005). Even though the conjoint uses of cottonseed oil in food making, their role in human lipid metabolism remains mainly unidentified (Radcliffe et al., 2001). According to Radcliffe and CzajkaNarins (2006) working on animals (rats) have showed that by changing of corn oil with CSO consecutive for four weeks reduced total cholesterol along with HDL levels. Furthermore they assumed that blood lipid lowering effects of CSO may be due to the nonsaponifiable portion of this oil (Radcliffe et al., 2001) which comprises of alphatocopherol and beta sitosterol (Lloyd-Jones et al., 2010).

\subsection{Anti-allergic response of cottonseed oil}

Numerous studies were performed to evaluate cottonseed oil under allergic and toxicological responses. Under such circumstances, CSO played vital role of defense in allergic response. Based on this idea, an experiment on cottonseed oil has shown to have adjuvant effect on the humoral response, thus motivating a secondary response that preferred the delayed-type hypersensitivity response to ovalbumin. The careful selection of adjuvants can affect certain features of antibody response like epitope specificity, affinity, class and/or isotype (Allison and Byars, 1991). Keeping in view the above facts, it is very crucial to conduct research work and develop novel immunologic adjuvants that possess very minute toxicity for the benefits of case under study. It needs accuracy and efficiency and widespread resources (Sun, 1998). Such responses may be achieved by using vegetable oils as they are the probable adjuvant sources. The supreme significant benefit of vegetable oils (cottonseed oil) is that they have minimal adverse side-effects as they are biodegradable compounds (Eghafona, 1996). This result supports the data from literature showing that emulsions made of oleic acid plus diphiteric toxoid strongly increased the IgG levels to that toxoid (Schröder and Svenson, 1999). A significant gain of using CSO as immunological adjuvants is that are metabolized very easily by a feeding organism (Eghafona, 1996).

\subsection{Anticancer activity of cottonseed oil}

Research findings on unsaturated fatty acids have been testified to prevent cancer cell growth (Chapkin et al. 2007; Huang et al. 2007; Lee and Bae, 2007; Sakai et al. 2006; Tsuzuki et al. 2007). While some saturated branched-chain fatty acids have been tested to display anticancer activity. Out of these, oleic acid is one of the utmost rich fatty acids of several vegetable oils like cottonseed oil. During this project novel and extended uses of oilseed products and by-products, methyl oleate was altered through various reactions to numerous diverse (methyl, n-butyl, phenyl) branched-chain derivatives (Dailey Junior and Prevost 2007; Dailey Junior et al., 2008). Under aseptic in vitro conditions, these compounds along with their free acid parts were investigated against two human cancer lines for their anti-proliferative activities. As genus gossypium comprises of gossypol and gossypol retains selective toxicity towards cancerous cells (Ambasta, 2000). Among cancer types, breast cancer is one of them which is mostly associated and diagnosed as women cancer. It has been investigated that obesity is a key risk element for emerging breast cancer. As there are several risk factors that women can modify to prevent cancer. As discussed above that gossypol-enriched cottonseed oil (GPCSO) possesses strong anticancer activity against multiple types of cancer, including breast cancer. Furthermore, (-)-GPCSO reduced body weight gain and food intake in young female rats. Although, the function of (-)-GPCSO on adipogenesis in human breast pre-adipocytes rests uncertain. According to the findings of Zhong et al. (2013) that GPCSO repressed increase of pre-adipocytes and thus down-regulated the expression of cyclin-D1 and BCL-2. They mentioned that (-)-GPCSO also ominously reduced adipogenesis, by inhibition of GPDH activity, triglyceride content (TG), and down-regulation of the expression of PPAR $\gamma, \mathrm{C} / \mathrm{EBP} \alpha$ and leptin. Cottonseed contains gossypol (GP), and it is a naturally occurring polyphenolic compound (Adams et al. 1960). In china initially it was recognized as an agent that play role in male infertility (National Coordinating Group on Male Antifertility Agents, 1979). In recent times, GP have anti-proliferative properties against a variety of human cancer cells lines like breast, ovary, prostate and colon (Liu et al. 2002a; Jiang et al. 2004; Zhang et al. 2003). After evaluation, it has been identified that such class (-)-GP is more effective than racemic GP. It was verified that the anti-proliferative effect of GP is mediated via induction of cellular apoptosis. Teng (1998) claimed that GP induced apoptosis in rat spermatocytes mediated by biphasic regulation of c-fos protein. Another confirmation that GP played role to induce DNA fragmentation after one and two day's interval in human colon carcinoma cell lines i.e. HT29 and LoVo respectively (Wang et al. 2000). Moreover, it has also been reported that GP possess apoptotic effect on human lymphocytes (Yurtcu et al. 2003). Chang et al. (2004) pointed out that GP prompted apoptosis in human alveolar lung cancer cell line A549 cells, mediated by up-regulation of Fas/FasL. Xu et al.(2005) reported that (-)-GP boosted the reaction to radiation therapy causing in tumor regression of human prostate cancer. Further reports are available regarding the role of GP of cottonseed and their oil to prompt apoptosis in human promyelocytic leukemia HL-60 cells through the reactive oxygen speciesindependent mitochondrial dysfunction pathway (Hou et al. 2004) and (-)-GP binds to the BH3-binding groove of Bcl-xL and $\mathrm{Bcl}-2$ protein. It has been presented that milk from cows fed a GP-containing cottonseed meal significantly inhibited the growth of MCF-7, multidrug-resistant MCF-7/Adr and RE-B2T rat esophageal carcinoma cells (Hu et al. 1994). One of the successful role of cottonseed oil in controlling human cancer prevalence based on epidemiological data from Russia reported that by using CSO having GP the chances of human cancer were reduced as compared to those countries where CSO not used as cooking oil in daily food consumption. 


\section{Antioxidant activity of CSO}

Cottonseed oil has shown its role in antioxidant activities due to presence of tocopherols. Pokorny et al. (2000) investigated that CSO possess antioxidant activities after proper testing. They reported that gossypol has shown stronger antiradical activity against the DPPH radical, based on $\mathrm{IC}_{50}$. Through the process of neutralization of the raw oil a waste product called soapstock is obtained. Some segments of GP permits on to the soapstock as natural a form or as an intricate with related constituents of the oil like phosphatides (Dowd, 1996; Kuk and Ballew, 1993). Numerous researchers mentioned antioxidant activity of GP attained from raw cotton oil (Mukhamediev et al., 1986; Cai et al., 2004; Sotelo et al., 2005; Wang et al., 2005; Boboev et al., 2012). As it is well defined that peroxide value (PV) is a measure of peroxides and hydro peroxides concentration formed in the initial stages of lipid oxidation. It has reported earlier that peroxide value is one of the best trials to test the measurement of primary oxidation in oils and fats. According to this finding, oxidation degree on cotton seed oil samples was determined by measuring peroxide value. Therefore, it has been well tested that cottonseed oil has antioxidant activity might be cause by tocopherols (Elsayed and Lobna, 2013).

\section{Conclusions}

This review covers the impact of CSO in the dimensions of physical properties, active ingredients involved, fatty acid compositions and their specific role and above all health benefits of CSO. Cottonseed oil plays its role in cardiovascular diseases, anti-allergic response, anticancer activity, antioxidant activity. The overall characteristics and all concerned health benefits of CSO will further improve their usefulness is a compact way. We have summarized brief multi-dimensional features of CSO in all aspects up to the best of our knowledge, and understanding for the end researchers who can do further research in the respective counterpart.

\section{References}

ABDELMOEZ, W., ABDELFATAH, R., TAYEB, A. and YOSHIDA, H., 2011. Extraction of cottonseed oil using subcritical water technology. AIChE Journal. American Institute of Chemical Engineers, vol. 57, no. 9, pp. 2353-2359. http://dx.doi.org/10.1002/aic.12454.

ABIDI, S.L., 2001. Chromatographic analysis of plant sterols in foods vegetable oils. Journal of Chromatography. A, vol. 935, no. 1-2, pp. 173-201. http://dx.doi.org/10.1016/S0021-9673(01)009463. PMid: 11762774.

ABOU-DONIA, M.B., 1976. Physiological effects and metabolism of gossypol. Residue Reviews, vol. 61, pp. 125-160. PMid:778955.

ADAMS, R., GEISSMAN, T.A. and EDWARDS, J.D., 1960. Gossypol, a pigment of cottonseed. Chemical Reviews, vol. 60, no. 6, pp. 555574. http://dx.doi.org/10.1021/cr60208a002. PMid:13681414.

ALLISON, A.C. and BYARS, N.E., 1991. Immunological adjuvants: desirable properties and side-effects. Molecular Immunology, vol. 28, no. 3, pp. 279-284. http://dx.doi.org/10.1016/01615890(91)90074-T. PMid:1850114.
AMARNI, F. and KADI, H., 2010. Kinetics study of microwaveassisted solvent extraction of oil from olive cake using hexane: comparison with the conventional extraction. Innovative Food Science E' Emerging Technologies, vol. 11, no. 2, pp. 322-327. http://dx.doi.org/10.1016/j.ifset.2010.01.002.

AMBASTA, S.P., 2000. The useful plant of India. 4th ed. Delhi: National Institution of Sci. Communication, pp.243.

APPLEQUIST, W.L., CRONN, R. and WENDEL, J.F., 2001. Comparative development of fiber in wild and cultivated cotton. Evolution $\mathcal{E}$ Development, vol. 3, no. 1, pp. 3-17. http://dx.doi.org/10.1046/ j.1525-142x.2001.00079.x. PMid:11256432.

ASHRAF, M., 2002. Salt tolerance of cotton. Critical Reviews in Plant Sciences, vol. 21, no. 1, pp. 1-30. http://dx.doi.org/10.1080/0735260291044160.

AZADMARD-DAMIRCHI, S., HABIBI-NODEH, F., HESARI, J., NEMATI, M. and ACHACHLOUEI, B.F., 2010. Effect of pretreatment with microwaves on oxidative stability and nutraceuticals content of oil from rapeseed. Food Chemistry, vol. 121, no. 4, pp. 1211-1215. http://dx.doi.org/10.1016/j.foodchem.2010.02.006.

BAILEY, A.E., editor Cottonseed and cottonseed products. New York: Interscience Publisher, Inc., 1948, pp. 364-408.

BAILEY, A.V., HARRIS, J.A., SKAU, E.L. and KERR, T., 1966. Cyclopropenoid fatty acid content and fatty acid composition of crude oils from twenty-five varieties of cottonseed. Journal of the American Oil Chemists' Society, vol. 43, no. 2, pp. 107-110. http://dx.doi.org/10.1007/BF02641028.

BALIGA, B.P. and LYMAN, C.M., 1957. Preliminary report on the nutritional significance of bound gossypol in cottonseed meal. Journal of the American Oil Chemists' Society, vol. 34, no. 1, pp. 21-24. http://dx.doi.org/10.1007/BF02637931.

BERARDI, L.C. and GOLDBLATT, L.A., 1980. Gossypol toxic constituents of plant foodstuffs. 1st ed. New York: Academic Press, pp. 184-237.

BERTRAND, J.A., SUDDUTH, T.Q., CONDON, A., JENKINS, T.C. and CALHOUN, M.C., 2005. Nutrient content of whole cottonseed. Journal of Dairy Science, vol. 88, no. 4, pp. 1470-1477. http:// dx.doi.org/10.3168/jds.S0022-0302(05)72815-0. PMid:15778316.

BLAND, J.M., CONKERTON, E.J., ABRAHAM, G. and AMER, J., 1991. Triacylglyceride composition of cottonseed oil by HPLC and GC. Journal of the American Oil Chemists' Society, vol. 68, no. 11, pp. 840-843. http://dx.doi.org/10.1007/BF02660598.

BOBOEV, A., HASANOV, A., YOTOVA, L., and HASANOV, H., 2012. Antioxidant activity of peptides obtained from wheat and cottonseed proteins. Bulgarian Journal of Agricultural Science, vol. 18, no. 1, pp. 103-111.

CAI, Y., ZHANG, H., ZENG, Y., MO, J., BAO, J., MIAO, C., BAI, J., YAN, F. and CHEN, F., 2004. An optimized gossypol high-performance liqiuid chromatography assay and its application in evaluation of different gland genotypes of cotton. Journal of Biosciences, vol. 29, no. 1, pp. 67-71. PMid:15286405.

CALHOUN, M.C., HUSTON, J.E., CALK, C.B., BALDWIN, B.C. and KUHLMANN, S.W., 1991. Effects of gossypol on digestive and metabolic function of domestic livestock. In: L.A. JONES, D.H. KINARD and J.S. MILLS, eds. Cattle research with gossypol containing feeds: a collection of papers addressing gossypol effects in cattle. Memphis: National Cottonseed Products Assoc., pp. 39.

CAMEL, V., 2000. Microwave-assisted solvent extraction of environmental samples. Trends in Analytical Chemistry, vol. 19, no. 4, pp. 229-248. http://dx.doi.org/10.1016/S01659936(99)00185-5.

CARSON, J.A., BURKE, F.M. and HARK, L.A., 2005. Cardiovascular nutrition: disease management and prevention. Chicago, IL, USA: American Dietetic Association. 
CHANG, J.S., HSU, Y.L., KUO, P.L., CHIANG, L.C. and LIN, C.C., 2004. Upregulation of Fas/Fas ligand-mediated apoptosis by gossypol in an immortalized human alveolar lung cancer cell line. Clinical and Experimental Pharmacology \& Physiology, vol. 31, no. 10, pp. 716-722. http://dx.doi.org/10.1111/j.1440-1681.2004.04078.x. PMid:15554914.

CHAPKIN, R.S., MCMURRAY, D. and LUPTON, J., 2007. Colon cancer, fatty acids and anti-inflammatory compounds. Current Opinion in Gastroenterology, vol. 23, no. 1, pp. 48-54. http://dx.doi. org/10.1097/MOG.0b013e32801145d7. PMid:17133085.

CHEMAT, S., AÏT-AMAR, H., LAGHA, A. and ESVELD, D.C., 2005. Microwave-assisted extraction kinetics of terpenes from caraway seeds. Chemical Engineering and Processing, vol. 44, no. 12, pp. 1320-1326. http://dx.doi.org/10.1016/j.cep.2005.03.011

CHERRY, J.P., 1983. Cottonseed oil. Journal of the American Oil Chemists'Society, vol. 60, no. 2Part2, pp. 360-367. http://dx.doi. org/10.1007/BF02543519.

CONKERTON, E.J., WAN, P.J. and RICHARD, O.A., 1995. Hexane and heptane as extraction solvents for cottonseed: A laboratoryscale study. Journal of the American Oil Chemists' Society, vol. 72, no. 8, pp. 963-965. http://dx.doi.org/10.1007/BF02542075.

DAILEY JUNIOR, O. and PREVOST, N., 2007. Conversion of methyl oleate to branched-chain derivatives. Journal of the American Oil Chemists' Society, vol. 84, no. 6, pp. 565-571. http://dx.doi. org/10.1007/s11746-007-1077-x.

DAILEY JUNIOR, O., PREVOST, N. and STRAHAN, G., 2008. Synthesis and structural analysis of branched-chain derivatives of methyl oleate. Journal of the American Oil Chemists' Society, vol. 85, no. 7, pp. 647-653. http://dx.doi.org/10.1007/s11746-008-1235-9.

DAVIS, K.E., PRASAD, C. and IMRHAN, V., 2012. Consumption of a diet rich in ottonseed Oil (CSO) lowers total and LDL cholesterol in normo-cholesterolemic subjects. Nutrients, vol. 4, no. 7, pp. 602-610. http://dx.doi.org/10.3390/nu4070602. PMid:22852052.

DOWD, M.K., 1996. Compositional characterization of cottonseed soapstocks. Journal of the American Oil Chemists' Society, vol. 73, no. 10, pp. 1287-1291. http://dx.doi.org/10.1007/BF02525458.

EAVES, P.H., DUPUY, H.P., HOLZENTHAL, L.L., RAYNER, E.T. and BROWN, L.E., 1968. Elimination of the Halphen response of cottonseed oils in conjunction with deodorization. Journal of the American Oil Chemists' Society, vol. 45, no. 4, pp. 293-295. http://dx.doi.org/10.1007/BF02652430 PMid:5694339.

ECKEL, R.H., BORRA, S., LICHTENSTEIN, A.H. YIN-PIAZZA, S.Y., and TRANS FAT CONFERENCE PLANNING GROUP, 2007. Understanding the complexity of trans fatty acid reduction in the American diet: American Heart Association Trans Fat Conference 2006: report of the Trans Fat Conference Planning Group. Circulation, vol. 115, no. 16, pp. 2231-2246. http://dx.doi. org/10.1161/CIRCULATIONAHA.106.181947. PMid:17426064.

EGHAFONA, N.O., 1996. Immune responses following cocktails of inactivated measles vaccine and Arachis hypogaea L. (groundnut) or Cocos nucifera L. (coconut) oils adjuvant. Vaccine, vol. 14, no. 17-18, pp. 1703-1706. http://dx.doi.org/10.1016/S0264410X(96)00051-5. PMid:9032902.

ELANGOVAN, A.V., TYAGI, P.K., SHRIVASTAV, A.K., TYAGI, P.K. and MANDAL, A.B., 2006. GMO (Bt-Cry1Ac gene) cottonseed meal is similar to non-GMO low free gossypol cottonseed meal for growth performance in broiler chickens. Animal Feed Science and Technology, vol. 12, no. 3-4, pp. 252-263. http://dx.doi. org/10.1016/j.anifeedsci.2005.12.014.

ELSAYED, E. and LOBNA, S., 2013. Hypolipidemic activities of hydroalcoholic extract of avocado fruit on high cholesterol fed diet in rats and its antioxidant effect in vitro. Journal of the American Oil Chemists' Society, vol. 9, no. 12, pp. 337-343.
ENCYCLOPEDIA AMERICANA INTERNATIONAL. 2001 Encyclopedia Americana International Edition. Danbury, United States: Grolier Inc.<bok>

ERTUGRUL, D. and FILIZ, K., 2004. Using of cottonseed oil as an environmentally accepted Lubricant additive. Energy Sources. Part A, Recovery, Utilization, and Environmental Effects, vol. 26, no. 7, pp. 611-625.

FENG, H. J., 2010. Allosteric modulation of GABAA receptors. Pharmaceuticals, vol. 3, no. 11. http://dx.doi.org/10.3390/ ph3113461.

FERRAEI, R.A., SCHULTE, E., ESTEVES, W., BRUHL, L. and MUKHERJEE, K.D., 1989. Minor constituents of vegetable oils during industrial processing. Journal of the American Oil Chemists' Society, vol. 66, pp. 118-120.

FERRARI, R.A., ESTEVES, W., MUKHERJEE, K.D. and SCHULTE, E., 1997. Alteration of sterols and steryl eters in vegetable oils during industrial refining. Journal of Agricultural and Food Chemistry, vol. 45, no. 12, pp. 4753-4757. http://dx.doi.org/10.1021/jf970525j.

FIRESTONE, D., 1999. Physical and chemical characteristics of oils, fats, and waxes. Champaign, Illinois: AOCS Press, pp. 32-33.

FLETCHER, B., BERRA, K., ADES, P., BRAUN, L.T., BURKE, L.E., DURSTINE, J.L., FAIR, J.M., FLETCHER, G.F., GOFF, D., HAYMAN, L.L., HIATT, W.R., MILLER, N.H., KRAUSS, R., KRIS-ETHERTON, P., STONE, N., WILTERDINK, J., WINSTON, M., COUNCIL ON CARDIOVASCULAR NURSING, COUNCIL ON ARTERIOSCLEROSIS, THROMBOSIS, AND VASCULAR BIOLOGY, COUNCIL ON BASIC CARDIOVASCULAR SCIENCES, COUNCIL ON CARDIOVASCULAR DISEASE IN THE YOUNG, COUNCIL ON CLINICAL CARDIOLOGY, COUNCIL ON EPIDEMIOLOGY AND PREVENTION, COUNCIL ON NUTRITION, PHYSICAL ACTIVITY, AND METABOLISM, COUNCIL ON STROKE, and PREVENTIVE CARDIOVASCULAR NURSES ASSOCIATION, 2005. Managing abnormal blood lipids: a collaborative approach. Circulation, vol. 112, no. 20, pp. 31843209. http://dx.doi.org/10.1161/CIRCULATIONAHA.105.169180. PMid:16286609.

FLIDER, F.J. and ORTHOEFER, F.T., 1981. Metals in soybean oil. Journal of the American Oil Chemists' Society, vol. 58, no. 3 pt 1, pp. 270-272. http://dx.doi.org/10.1007/BF02582354.

FOOD AND AGRICULTURE ORGANIZATION - FAO 2003. State of the World's Forests 2003. Rome. Available from: ftp.fao.org/ docrep/fao/005/y7581e/

FORSTER JUNIOR, L.A. and CALHOUN, M.C., 1995. Nutrient values for cottonseed products deserve a new look. Feedstuffs., vol. 67, no. 44, pp. 16.

FRAMPTON, V.L., KUCK, J.C., PEPPERMAN, A.B. Jr., PONS, W.A. Jr., WATTS, A.B. and JOHNSTON, C., 1966. Some physiological properties of Halphen-positive cottonseed oils. Poultry Science, vol. 45, no. 3, pp. 527-535. http://dx.doi.org/10.3382/ps.0450527.

GANDHI, A.P., JOSHI, K.C., JHA, K., PARIHAR, V.S., SRIVASTAV, D.C., RAGHUNADH, P., KAWALKAR, J., JAIN, S.K. and TRIPATHI, R.N., 2003. Studies on alternative solvents for the extraction of oil-I soybean. International Journal of Food Science E' Technology, vol. 38, no. 3, pp. 369-375. http://dx.doi.org/10.1046/j.13652621.2003.00683.x.

GERASIMIDIS, K., FILLOU, D., BABATZIMCPOULOU, M., TASSOU, K. and KATSIKAS, H., 2007. Preparation of an edible cottonseed protein concentrate and evaluation of its functional properties. International Journal of Food Sciences and Nutrition, vol. 58, no. 6, pp. 486-490. http://dx.doi.org/10.1080/09637480701288488. PMid:17710592.

GROB, K., ARTHO, A. and MARIANI, C., 1992. Determination of raffination of edible oils and fats by olefinic degradation products 
of sterols and squalen, using coupled LC-GC. European Journal of Lipid Science and Technology, vol. 94, no. 10, pp. 394-399.

HARRIS, J.A., MAGNE, F.C. and SKAU, E.L., 1964. Methods for the determination of cyclopropenoid fatty acids. IV. Application of the step-wise $\mathrm{HBr}$ titration method to the analysis of refined and crude cottonseed oils. Journal of the American Oil Chemists Society, vol. 41, no. 4, pp. 309-311. http://dx.doi.org/10.1007/ BF02667026.

HARRIS, W.S., MOZAFFARIAN, D., RIMM, E., KRIS-ETHERTON, P., RUDEL, L.L., APPEL, L.J., ENGLER, M.M., ENGLER, M.B. and SACKS, F., 2009. Omega-6 fatty acids and risk for cardiovascular disease: a science advisory from the American Heart Association Nutrition Subcommittee of the Council on Nutrition, Physical Activity, and Metabolism. Circulation, vol. 119, no. 6, pp. 902907. PMid:19171857.

HENDRIX, B. and STEWART, J., 2005. Estimation of the nuclear DNA content of gossypium species. Annals of Botany, vol. 95, no. 5, pp. 789-797. http://dx.doi.org/10.1093/aob/mci078. PMid: 15701660.

HOFFMANN, G., 1989. The chemistry and technology of edible oils and fats and their fat products. New York: Academic, pp. 139200. http://dx.doi.org/10.1016/B978-0-12-352055-5.50011-5.

HOU, D.X., UTO, T., TONG, X., TAKESHITA, T., TANIGAWA, S., IMAMURA, I., OSE, T. and FUJII, M., 2004. Involvement of reactive oxygen species-independent mitochondrial pathway in gossypol induced apoptosis. Archives of Biochemistry and Biophysics, vol. 428, no. 2, pp. 179-187. http://dx.doi.org/10.1016/j. abb.2004.06.007. PMid:15246875.

HU, Y.F., CHANG, C.J., BRUEGGEMEIER, R.W. and LIN, Y.C., 1994. Presence of antitumor activities in the milk collected from gossypol-treated dairy cows. Cancer Letters, vol. 87, no. 1, pp. 17-23. http://dx.doi.org/10.1016/0304-3835(94)90404-9. PMid:7954365.

HUANG, G., ZHONG, X., CAO, Y. and CHEN, Y., 2007. Antiproliferative effects of conjugated linoleic acid on human colon adenocarcinoma cell line Caco-2. Asia Pacific Journal of Clinical Nutrition, vol. 16, no. 1, suppl. 1, pp. 432-436. PMid:17392145.

JIANG, J., SUGIMOTO, Y., LIU, S., CHANG, H.L., PARK, K.Y., KULP, S.K. and LIN, Y.C., 2004. The inhibitory effects of gossypol on human prostate cancer cells - PC3 are associated with transforming growth factor beta1 (TGFbeta1) signal transduction pathway. Anticancer Research, vol. 24, no. 1, pp. 91-100. PMid:15015581.

JONES, L. and KING, C., 1996. Cottonseed oil. In: Y.H. HUI, ed. Baileys industrial oil and fat products. New York: John Wiley \& Sons, Inc., vol. 2, pp. 166-209, chap. 4.

JONES, L.A., 1991. Definition of gossypol and its prevalence in cottonseed products. In: L.A. JONES, D.H. KINARD and J.S. MILLS. eds. Cattle research with gossypol containing feeds: a collection of papers addressing gossypol effects in cattle. Memphis: National Cottonseed Products Assoc.

KHAN, N. and HASSAN, G., 2011. Genetic effects on morphological and yield traits in cotton (Gossypium hirsutum L.). Spanish Journal of Agricultural Research, vol. 9, no. 2, pp. 460-472. http:// dx.doi.org/10.5424/sjar/20110902-166-10.

KIM, H.J. and TRIPLETT, B.A., 2001. Cotton fiber growth in planta and in vitro. Models for plant cell elongation and cell wall biogenesis. Plant Physiology, vol. 127, no. 4, pp. 1361-1366. http://dx.doi.org/10.1104/pp.010724 PMid:11743074.

KIRK, J.H. and HIGGINBOTHAM, G.E., 1999. PIMA cotton, gossypol and dairy cattle- is it a bad combination?. The Western Dairyman, vol. 80, no. 8, pp. 32-33.
KUK, M.S. and BALLEW, A.G., 1993. The potential of soap stock derived film: cottonseed and safflower. Journal of the American Oil Chemists' Society, vol. 76, no. 11, pp. 1367-1369.

KUK, M.S., TETLOW, R. and DOWD, M.K., 2005. New and expanded uses of oilseed products and by products. Journal of the American Oil Chemists' Society, vol. 82, no. 8, pp. 609-612.

LEE, M. and BAE, M., 2007. Docosahexaenoic acid induces apoptosis in CYP2E1-containing HepG2 cells by activating the c-Jun Nterminal protein kinase related mitochondrial damage. The Journal of Nutritional Biochemistry, vol. 18, no. 5, pp. 348-354. http://dx.doi.org/10.1016/j.jnutbio.2006.06.003. PMid:16963249.

LEONE, A.M., LIUZZI, V., LA NOTTE, E. and SANTORO, M., 1984. Steroli, metilsterolie dimetilsteroli di alcuni oli vegetali con particolare riguardo a quelli di olive. Possibile loro ruolo nella caratterizzazione di alcuni prodotti.Loro variazione nel processo di rettifica. La Rivista Italiana delle Sostanze Grasse, vol. 61, pp. 69-89.

LIAUW, M.Y., NATAN, F.A., WIDIYANTI, P., IKASARI, D., INDRASWATI, N. and SOETAREDJO, F.E., 2008. Extraction of neem oil (Azadirachta indica A. Juss) using n-hexane and ethanol: studies of oil quality, kinetic and thermodynamic. ARPN Journal of Engineering and Applied Sciences, vol. 3, no. 3, pp. 49-54.

LISA, M. and HOLCAPEK, M., 2008. Triacylglycerols profiling in plant oils important in food industry, dietetics and cosmetics using high-performance liquid chromatography-atmospheric pressure chemical ionization mass spectrometry. Journal of Chromatography. A, vol. 1198-1199, pp. 115-130. http://dx.doi. org/10.1016/j.chroma.2008.05.037. PMid:18539288.

LIU, Q., SINGH, S. and GREEN, A., 2000. Genetic modification of cotton seed oil using inverted-repeat gene-silencing techniques. Biochemical Society Transactions, vol. 28, no. 6, pp. 927-929. http://dx.doi.org/10.1042/bst0280927. PMid:11288706.

LIU, Q., SINGH, S. and GREEN, A., 2002a. High-oleic and high-stearic cottonseed oils: nutritionally improved cooking oils developed using gene silencing. Journal of the American College of Nutrition, vol. 21, no. 3, (suppl.), pp. 205S-211S. http://dx.doi.org/10.108 0/07315724.2002.10719267. PMid:12071306.

LIU, Q., SINGH, S.P., BRUBAKER, C.L., SHARP, P.J., GREEN, A.G. and MARSHALL, D.R., 1999. Molecular cloning and expression of a cDNA encoding a microsomal_-6 fatty acid desaturase in cotton (Gossypium hirsutum L.). Australian Journal of Plant Physiology, vol. 26, pp. 101-106.

LIU, Q., SINGH, S.P., SHARP, P.J., GREEN, A.G. and MARSHALL, D.R., 1996. Nucleotide sequence of a cDNA from Gossypium hirsutum encoding a stearoyl-acyl carrier protein desaturase (Accession No. X95988) (OGR 96-012). Plant Physiology, vol. 110, pp. 1435.

LIU, S., KULP, S.K., SUGIMOTO, Y., JIANG, J., CHANG, H.L., DOWD, M.K., WAN, P. and LIN, Y.C., 2002b. The (-)-enantiomer of gossypol possesses higher anticancer potency than racemic gossypol in human breast cancer. Anticancer Research, vol. 22, no. 1A, pp. 33-38. PMid:12017312.

LLOYD-JONES, D.M., HONG, Y., LABARTHE, D., MOZAFFARIAN, D., APPEL, L.J., VAN HORN, L., GREENLUND, K., DANIELS, S., NICHOL, G., TOMASELLI, G.F., ARNETT, D.K., FONAROW, G.C., HO, P.M., LAUER, M.S., MASOUDI, F.A., ROBERTSON, R.M., ROGER, V., SCHWAMM, L.H., SORLIE, P., YANCY, C.W., ROSAMOND, W.D., and AMERICAN HEART ASSOCIATION STRATEGIC PLANNING TASK FORCE AND STATISTICS COMMITTEE, 2010. Defining and setting national goals for cardiovascular health promotion and disease reduction: The American Heart Association's Strategic Impact Goal Through 2020 and Beyond. Circulation, vol. 121, no. 4, pp. 586-613. http://dx.doi.org/10.1161/ CIRCULATIONAHA.109.192703. PMid:20089546. 
LO, K.V., BULLEY, N.C.R. and KWONG, E., 1985. Sequencing aerobic batch reactor treatment of milking parlour wastewater. Agricultural Wastes, vol. 13, no. 2, pp. 131-136. http://dx.doi. org/10.1016/0141-4607(85)90019-8.

MELCER, H., BEDFORD, W.K., TOPNIK, B.H. and SCHMIDTKE, N.W., 1987. Title. JWPCF, vol. 59, pp. 19.

MUKHAMEDIEV, M.G., AUELBEKOV, S.A., SHARIPOVA, Z.T., BABAEV, T.M., MUSAEV, U.N. and ASLANOV, K.A., 1986. Polymer complexes of gossypol and their antiviral activity. Pharmaceutical Chemistry Journal, vol. 20, no. 4, pp. 276-278. http://dx.doi.org/10.1007/ BF00758817.

NATIONAL COORDINATING GROUP ON MALE ANTIFERTILITY AGENTS, 1979. Gossypol - a new antifertility agent for males. Gynecologic and Obstetric Investigation, vol. 10, no. 4, pp. 163-176. http://dx.doi.org/10.1159/000299937. PMid:393575.

NORCIA, L.N. and ROSENTHAL, B.E., 1996. Sterol content of some plant oils; further observations on fast-reacting sterols. Journal of the American Oil Chemists' Society, vol. 43, no. 3, pp. 168-170. http://dx.doi.org/10.1007/BF02646295. PMid:5907623.

O'BRIEN, J., WILSON, I., ORTON, T. and POGNAN, F., 2000. Investigation of the Alamar Blue (resazurin) fluorescent dye for the assessment of mammalian cell cytotoxicity. European Journal of Biochemistry, vol. 267, no. 17, pp. 5421-5426. http:// dx.doi.org/10.1046/j.1432-1327.2000.01606.x PMid:10951200.

O'BRIEN, R.D.O. and WAKELYN, P.J., 2005. Cottonseed oil: an oil for trans-free options. Journal of Food Technology, vol. 16, no. 11, pp. 677-679.

O'BRIEN, R.D. and WAN, P.J., 2001. Cottonseed oil: processing and utilization. In: R. WILSON, eds. Proceedings of the World Conference and Exhibition on Oilseed Processing and Utilization. Champaign, IL : AOCS Press, pp. 16.

PALIS, J.C. and IRVINE, R.L., 1985. Nitrogen removal in a low-loaded single tank sequencing batch reactor. Journal - Water Pollution Control Federation, vol. 57, no. 1, pp. 82-86.

PARK WALDROUP and NATIONAL COTTONSEED PRODUCTS ASSOCIATION - NCPA, 2000. NCPA oil mill industry survey. USA: NCPA. Summary, Industry Data. NCPA Technical Files. 1999 Data collection.

PENNINGTON, J.A.T. and BOWES, A.P., 1994. Bowes and Church's food values of portions commonly used. New York: J. B. Lippincott Co.

PERCIVAL, A.E., WENDEL, J.E. and STEWART, J.M., 1999. Cotton origin, history, technology and production. New York: John Wiley and Sons, pp. 33-63.

PHELPS, R.A., SHENSTONE, F.S., KEMMERER, A.R. and EVANS, R.J., 1965. A review of cyclopropenoid compounds: biological effects of some derivatives. Poultry Science, vol. 44, no. 2, pp. 358-394. http://dx.doi.org/10.3382/ps.0440358. PMid:14340723.

POKORNY, J., YANISHLIEVA, N. and GORDON, M. (2000). Antioxidants in food: practical applications. New York: CRC Press.

RADCLIFFE, J.D. and CZAJKA-NARINS, D.M., 2006. Lipids and tocopherols in serum and liver of female rats fed diets containing corn oil or cottonseed oil. Plant Foods for Human Nutrition (Dordrecht, Netherlands), vol.61, no. 1, pp. 35-38. http://dx.doi. org/10.1007/s11130-006-0011-y. PMid:16736386.

RADCLIFFE, J.D., KING, C.C., CZAJKA-NARINS, D.M. and IMRHAN, V., 2001. Serum and liver lipids in rats fed diets containing corn oil, cottonseed oil, or a mixture of corn and cottonseed oils. Plant Foods for Human Nutrition (Dordrecht, Netherlands), vol. 56, no. 1, pp. 51-60. http://dx.doi.org/10.1023/A:1008189503099. PMid:11213168.

SAKAI, Y., SASAHIRA, T., OHMORI, H., YOSHIDA, K. and KUNIYASU, H., 2006. Conjugated linoleic acid reduced metastasized LL2 tumors in mouse peritoneum. Virchows Archiv, vol. 449, no. 3, pp. 341-347. http://dx.doi.org/10.1007/s00428-006-0249-7. PMid: 16896890.

SAWAN, M.Z., HAFEEZ, S., BASYONY, A.E. and ALKASSAS, R., 2006. Cottonseed, protein, oil yields and oil properties as affected by nitrogen fertilization and foliar application of potassium and a plant growth retardant. World Journal of Agricultural Sciences, vol. 2, pp. 56-65.

SAXENA, D.K., SHSHARAND, S.K. and SAMBI, S.S., 2011. Comparative extraction of cottonseed oil by n-hexane and ethanol. Journal of Engineering and Applied Sciences (Asian Research Publishing Network), vol. 6, pp. 84-89.

SAYYAR, S., ABIDIN, Z.Z., YUNUS, R. and MUHAMMAD, A., 2009. Extraction of Oil from Jatropha Seeds-Optimization and Kinetics. American Journal of Applied Sciences, vol. 6, no. 7, pp. 1390-1395. http://dx.doi.org/10.3844/ajassp.2009.1390.1395.

SCHRÖDER, U. and SVENSON, S.B., 1999. Nasal and parenteral immunizations with diphtheria toxoid using monoglyceride/ fatty acid lipid suspensions as adjuvants. Vaccine, vol. 17, no. 15-16, pp. 2096-2103. http://dx.doi.org/10.1016/S0264410X(98)00408-3. PMid:10217612.

SEKHAR, S.C. and RAO, V.K.B., 2011. Cottonseed oil as health oil. Pertanika. Journal of Tropical Agricultural Science, vol. 34, pp. 17-24.

SHAHIDI, F., 2005. Bailey's industrial oil and fat products. New Jersey: John Wiley \& Sons. http://dx.doi.org/10.1002/047167849X.

SHENSTONE, F.S. and VICKERY, J.R., 1961. Occurrence of cyclopropene acids in some plants of the order Malvales. Nature, vol. 190, no. 4771, pp. 168-169. http://dx.doi.org/10.1038/190168b0.

SOTELO, A., VILLIAVICENCIO, H. and MONTALVO, I., 2005. Gossypol content on leaves and seeds from some wild Malveaceae species. African Journal of Traditional, Complementary, and Alternative Medicines, vol. 2, no. 1, pp. 4-12.

SUN, J.H., 1998. Research headway of immunopotentiator. Helongjiang Ani. Hus. Vet. Med., vol. 2, no. 4, pp. 40-42.

TAGHVAEI, M., JAFARI, S.M., ASSADPOOR, E., NOWROUZIEH, S. and ALISHAH, O., 2014. Optimization of microwaveassisted extraction of cottonseed oil and evaluation of its oxidative stability and physicochemical properties. Food Chemistry, vol. 160, pp. 90-97. http://dx.doi.org/10.1016/j. foodchem.2014.03.064. PMid:24799213.

TEAH, Y.K. and ONG, A.S.H., 1986. Palm oil and palm oil products for puff pastry margarine. Palm Oil Developments, vol. 4, pp. 17-18.

TENG, C.S., 1998. c-fos protein expression in apoptotic rat spermatocytes induced by gossypol. Contraception, vol. 57, no. 4, pp. 281-286. http://dx.doi.org/10.1016/S0010-7824(98)000237. PMid:9649921.

TERIGAR, B.G., BALASUBRAMANIAN, S., BOLDOR, D., XU, Z., LIMA, M. and SABLIOV, C.M., 2010. Continuous microwave-assisted isoflavone extraction system: design and performance evaluation. Bioresource Technology, vol. 101, no. 7, pp. 24662471. http://dx.doi.org/10.1016/j.biortech.2009.11.039. PMid:20018507.

TSUZUKI, T., KAMBE, T., SHIBATA, A., KAWAKAMI, Y., NAKAGAWA, K. and MIYAZAWA, T., 2007. Conjugated EPA activates mutant p53 via lipid peroxidation and induces p53-dependent apoptosis in DLD-1 colorectal adenocarcinoma human cells. Biochimica et Biophysica Acta, vol. 1771, no. 1, pp. 20-30. http://dx.doi. org/10.1016/j.bbalip.2006.11.006. PMid:17196878.

VAN ESBROECK, G. A., BOWMAN, D. T., MAY, O. L., and CALHOUN, D. S., 1999. Genetic similarity indices for ancestral cotton cultivars and their impact on genetic diversity estimates of 
modern cultivars. Crop Breeding, Genetics E' Cytology, vol. 39, no. 2, 323-328.<jrn>

WAN, P.J., PAKARINEN, D.R., HRON JUNIOR, R.J., RICHARD, O.L. and CONKERTON, E.J., 1995a. Alternative hydrocarbon solvents for cottonseed extraction. Journal of the American Oil Chemists' Society, vol. 72, no. 6, pp. 653-659. http://dx.doi.org/10.1007/ BF02635650.

WANG, J., WANG, X., CHEN, F., WAN, P.J., HE, G. and LI, Z., 2005. Development of competitive direct ELISA for gossypol analysis. Journal of Agricultural and Food Chemistry, vol. 53, no. 14, pp. 5513-5517. http://dx.doi.org/10.1021/jf050203c. PMid:15998107.

WANG, X., WANG, J., WONG, S.C.H., CHOW, L.S.N., NICHOLLS, J.M., WONG, Y.C., LIU, Y., KWONG, D.L.W., SHAM, J.S.T. and TSAO, S.W., 2000. Cytotoxic effect of gossypol on colon carcinoma cells. Life Sciences, vol. 67, no. 22, pp. 2663-2671. http://dx.doi. org/10.1016/S0024-3205(00)00857-2. PMid:11105982.

WENDEL, J. and CRONN, R.C., 2002. Polyploidy and the evolutionary history of cotton. Advances in Agronomy, vol. 78, pp. 139-186. http://dx.doi.org/10.1016/S0065-2113(02)78004-8.

XU, L., YANG, D., WANG, S., TANG, W., LIU, M., DAVIS, M., CHEN, J., RAE, J.M., LAWRENCE, T. and LIPPMAN, M.E., 2005. (-)-Gossypol enhances response to radiation therapy and results in tumor regression of human prostate cancer. Molecular Cancer Therapeutics, vol. 4, no. 2, pp. 197-205. PMid:15713891.

YURTCU, E., ERGUN, M.A. and MENEVSE, A., 2003. Apoptotic effect of gossypol on human lymphocytes. Cell Biology International, vol. 27, no. 9, pp. 791-794. http://dx.doi.org/10.1016/S10656995(03)00168-9. PMid:12972286.

ZHANG, M., LIU, H., GUO, R., LING, Y., WU, X., LI, B., ROLLER, P.P., WANG, S. and YANG, D., 2003. Molecular mechanism of gossypolinduced cell growth inhibition and cell death of HT-29 human colon carcinoma cells. Biochemical Pharmacology, vol. 66, no. 1, pp. 93-103. http://dx.doi.org/10.1016/S0006-2952(03)00248-X. PMid:12818369.

ZHONG, S., LEONG, J., YE, W., XU, P., LIN, S.H., LIU, J.Y. and LIN, Y.C., 2013. Gossypol-enriched cottonseed oil inhibits proliferation and adipogenesis of human breast pre-adipocytes. Anticancer Research, vol. 33, no. 3, pp. 949-955. PMid:23482766.

ZUNIN, P., BOCCA, A. and TISCORNIA, E., 1989. Studio dell'influenza del processo di rettificazione sulla composizione della frazione sterolica dell'olio di arachis hypogaea di soya hispida mediante GC capillare. La Rivista Italiana delle Sostanze Grasse, vol.66, pp. 133-137. 